\title{
Cerebrospinal fluid analysis in the HIV infection and compartmentalization of HIV in the central nervous system
}

\author{
Análise de LCR na infeção pelo HIV e compartimentalização do HIV no sistema \\ nervoso central
}

Sérgio Monteiro de Almeida ${ }^{1,2}$

\begin{abstract}
The nervous system plays an important role in HIV infection. The purpose of this review is to discuss the indications for cerebrospinal fluid (CSF) analysis in HIV infection in clinical practice. CSF analysis in HIV infection is indicated for the diagnosis of opportunistic infections and co-infections, diagnosis of meningitis caused by HIV, quantification of HIV viral load, and analysis of CNS HIV compartmentalization. Although several CSF biomarkers have been investigated, none are clinically applicable. The capacity of HIV to generate genetic diversity, in association with the constitutional characteristics of the CNS, facilitates the generation of HIV quasispecies in the CNS that are distinct from HIV in the systemic circulation. CSF analysis has a well-defined and valuable role in the diagnosis of CNS infections in HIV/AIDS patients. Further research is necessary to establish a clinically applicable biomarker for the diagnosis of HIV-associated neurocognitive disorders.
\end{abstract}

Keywords: HIV, AIDS, central nervous system, cognitive impairment, cerebrospinal fluid, viral load, biomarkers.

\section{RESUMO}

O sistema nervoso representa um papel importante na infecção pelo HIV. O objetivo desta revisão é discutir as indicações para análise do líquido cefalorraquidiano (LCR) na infecção pelo HIV na prática clínica. A análise do LCR na infecção pelo HIV é indicada para o diagnóstico de infecções oportunistas e co-infecções, meningite pelo HIV, quantificação da carga viral de HIV e compartimentalização do HIV no SNC. Uma série de biomarcadores no LCR foi investigada, na literatura, porém não apresentam aplicabilidade clínica. A grande capacidade do HIV de gerar diversidade genética, associado a características constitucionais do SNC propicia o desenvolvimento quasiespécies distintas no SNC das circulantes sistemicamente. A análise do LCR na infecção pelo HIV é bem estabelecida no diagnóstico de infecções no CNS, contudo mais pesquisas é necessária para estabelecer a aplicabilidade clínica dos biomarcadores no diagnóstico de desordens cognitivas associadas ao HIV.

Palavras-chave: HIV, AIDS, sistema nervoso central, alteração cognitiva, líquido cefalorraquidiano, carga viral, biomarcadores.

Almost forty years after it began, the HIV epidemic remains a challenging public health problem. The incidence of infection is increasing in some vulnerable groups, mainly young men who have sex with men (MSM) and older peo$\mathrm{ple}^{1,2}$. The nervous and the immune systems are HIV target organs $\mathrm{s}^{3,4,5}$. The introduction of highly active antiretroviral therapy (HAART) has changed the clinical situation for patients with AIDS, decreased the incidence of opportunistic infections, and thus lowered mortality. However, the incidence of neurological complications directly related to HIV has not decreased proportionally ${ }^{6}$, probably because of the low penetration of antiretroviral (ARV) drugs into the central nervous system (CNS), the neuronal toxicity of ARVs, or the persistence of neuronal lesions caused by HIV before treatment?

The purpose of this review is to discuss the indications for cerebrospinal fluid (CSF) analysis in HIV infection in clinical practice. CSF analysis during HIV infection is indicated for the diagnosis of opportunistic infections and co-infections; the diagnosis of meningitis, acute or chronic, caused by HIV; the quantification of HIV viral load in CSF; and the analysis of HIV compartmentalization in the $\mathrm{CNS}^{5}$. Table 1 summarizes CNS complications in HIV infection.

\footnotetext{
${ }^{1}$ Universidade Federal do Paraná, Departamento de Patologia Médica; Hospital de Clínicas, Laboratório de Clínica Patológica, Seção de Virologia, Curitiba PR, Brazil; ${ }^{2}$ Instituto de Pesquisa Pelé Pequeno Príncipe, Curitiba PR, Brazil.

Correspondence: Sérgio Monteiro de Almeida; Hospital de Clínicas, Seção de Virologia, Setor Análises Clínicas, Universidade Federal do Paraná; Rua Padre Camargo, 280; 80060-240 Curitiba PR, Brasil; E-mail: sergio.ma@ufpr.br

Conflict of interest: There is no conflict of interest to declare.

Received 19 November 2014; Received in final form 16 March 2015; Accepted 06 April 2015.
} 
Table 1. Central nervous system complications in HIV infection.

\begin{tabular}{|c|c|c|c|}
\hline \multirow{2}{*}{ Opportunistic infections } & \multirow{2}{*}{ Co-infections } & \multirow{2}{*}{ Directly related to HIV infection } & IRIS \\
\hline & & & After beginning treatment with ARV \\
\hline $\begin{array}{l}\text { a. Cryptococcus } \\
\text { neoformans } \\
\text { b. Toxoplasmosis } \\
\text { c. PML (JC virus) } \\
\text { d. Primary lymphoma }\end{array}$ & $\begin{array}{c}\text { a. Tuberculosis } \\
\text { b. Syphilis } \\
\text { c.Community-acquired } \\
\text { bacterial meningitis } \\
\text { d. Cysticercosis } \\
\text { e. Hepatitis C virus } \\
\text { f. Chagas disease } \\
\text { g. Schistosomiasis } \\
\text { h. Malaria }\end{array}$ & $\begin{array}{l}\text { a. Acute meningitis } \\
\text { b. Chronic meningitis } \\
\text { c. HAND } \\
\text { d. Peripheral neuropathy } \\
\text { e. Vacuolar myelopathy }\end{array}$ & $\begin{array}{l}\text { a. Opportunistic infections } \\
\text { b. Inflammatory disease }\end{array}$ \\
\hline
\end{tabular}

\section{OPPORTUNISTIC INFECTIONS AND CO-INFECTIONS}

CSF analysis is important for the diagnosis of opportunistic infections and co-infections in the CNS. Several diagnostic methods can be used. The operational characteristics of each method differ according to the etiological agents under investigation $^{8,9,10}$. In AIDS, more than one opportunistic infection can co-exist because of immunosuppression.

Co-infections are prevalent in the population. They can occur in association with HIV infection, independent of immunosuppression ${ }^{11}$. Table 1 shows the most common etiologies of CNS co-infections that occur with HIV in Brazil.

\section{CNS COMPLICATIONS DIRECTLY RELATED TO HIV INFECTION}

\section{Acute meningitis caused by HIV}

Acute meningitis is present in $5 \%-10 \%$ of HIV-infected patients, usually before seroconversion, as well as during or after the observation of mononucleosis-like signs and symptoms. Its clinical evolution is self-limited. Acute meningitis can be asymptomatic or accompanied by focal neurological signs such as peripheral facial palsy.

The CSF has a biochemical and cellular pattern compatible with that of acute viral meningitis ${ }^{6}$. Anti-HIV enzyme-linked immunosorbent assays (ELISA) often yield negative results with blood and CSF samples. Because HIV/AIDS is a systemic infection, diagnostic tests (triage and confirmatory) must be performed using peripheral blood samples, not CSF samples ${ }^{1}$.

Patients with a risk of HIV infection are advised to have a second serological diagnosis test for HIV after 4-6 weeks ${ }^{1}$. No specific biomarker in the CSF or blood helps diagnose acute meningitis caused by HIV. The p24 antigen test for early diagnosis of HIV using blood samples is neither sensitive nor standardized for CSF analysis.

\section{Chronic meningitis caused by HIV}

Chronic meningitis is present in $40 \%$ of infected individuals at any infection stage, while $59 \%$ are asymptomatic.
Because it is an exclusion diagnosis, other causes of chronic meningitis must be ruled out. The CSF presents with pleocytosis $\left(5-50\right.$ cells $\left./ \mathrm{mm}^{3}\right)$ and increased total protein level (50-100 mg/dL); glucose, the CSF/blood glucose ratio, and lactic acid are in the normal range $\mathrm{e}^{8,12,13}$.

\section{Other neurologic complications associated with HIV}

The use of CSF analysis for the specific diagnosis of HIV-associated neurocognitive disorders (HAND), HIV myelopathy, and immunological recovery inflammatory syndrome (IRIS-HIV) is of limited clinical importance. Specific biomarkers for the diagnosis of these diseases have not been identified, although several have been studied.

HAND is the main neurologic complication directly associated with HIV infection ${ }^{14}$; it is a clinical diagnosis ${ }^{6,7,15}$. CSF analysis is important for ruling out opportunistic infections and co-infections. Several biomarkers in CSF with the potential to diagnose HAND have been studied. However, they are not clinically applicable $\mathrm{e}^{16,17,18,19,20}$ and are only used in research. With the aging of the HIV population, other biomarkers have become important and have been investigated ${ }^{21,22,23,24}$. The same can be applied to polyneuropathies and myelopathy associated with HIV. HIV vacuolar myelopathy occurs in $10 \%$ of patients with AIDS; it is an exclusion diagnosis. Other frequent causes of myelopathy, such as neurosyphilis, HTLV, $\mathrm{CMV}$, and specific endemic etiologies, must be ruled out.

Neurons do not have a CD4 receptor, the main receptor involved in HIV cell invasion; consequently, HIV does not infect neurons. Neuronal injury in HIV infection results from an indirect mechanism due to the complex interaction of anions, inflammatory and neuronal injury proteins and also constitutional HIV proteins ${ }^{4}$. These proteins are investigated as biomarkers in CSF or serum for CNS HIV infection and are summarized in Table 2. It is possible that pyroptosis plays an important role in neuronal lesion and death. Pyroptosis markers in the CSF of patients infected with HIV have not yet been studied. The mechanism of cell death, namely, apoptosis, which here can be described as the death of cells with a productive infection caused by HIV, does not depend on the inflammatory process; it is associated with the activation 
of caspase-3. Recently, a mechanism of cell death in HIVinfected cells, called pyroptosis, has been described. The term pyroptosis refers to proinflammatory programmed cell death, a form of cells death intermediate between apoptosis and necrosis. Pyroptosis is dependent on caspase-1, which in turn depends on inflammatory processes. Caspase- 1 is not involved in apoptotic cell death, and caspase-1-deficient cells respond normally to most apoptotic signals. The HIV-1-induced death of CD4 T lymphocytes is mediated by pyroptosis. The two mechanisms of programmed cell death, apoptosis and pyroptosis, are not exclusive ${ }^{25,26,27}$.

The CD4 and CD8 lymphocyte counts in the peripheral blood and the CD4/CD8 ratio are valuable biomarkers for immunological status in HIV/AIDS. In the CSF, they are of limited value because their changes reflect the changes in the peripheral blood ${ }^{28}$. For CSF analysis, some authors have suggested combining biomarkers for different conditions, such as neopterin to assess immunoactivation and light neurofilaments to evaluate neurodegeneration ${ }^{29}$.

IRIS-HIV is characterized by the occurrence of opportunistic infections or non-infectious inflammatory disease within weeks of initiating or changing ARV treatment, despite improvements in immunological status. About $15 \%-$ $25 \%$ of patients that receive ARV treatment develop IRISHIV within the first few months of therapy. The nervous

Table 2. Biomarkers of HIV and central nervous system (CNS) infection $15,17,18,19,59$.

\begin{tabular}{lc}
\hline \multicolumn{1}{c}{ Blood brain barrier } & CSF/ serum albumin ratio \\
\hline Lymphocytes & CD4, CD8, CD4/CD8 \\
$\beta-2$ microglobulin & Soluble CD14 \\
Neopterin \\
Quinolinic acid
\end{tabular}

system is a frequent target. Biomarkers in the CSF that diagnose IRIS have not yet been identified; the diagnosis is based on clinical criteria ${ }^{30,31}$.

\section{HIV VIRAL LOAD IN THE CSF}

HIV particles present in the CSF can have different origins: they can drain from perivascular spaces or infected cells of the meninges, or they can originate in the plasma and pass through the choroid plexus during CSF production, particularly in the case of damage to or inflammation of the choroid plexus $^{12}$. In clinical practice, determining the HIV viral load in the CSF is important for monitoring the therapeutic effects of ARV treatment, for identifying patients with CNS escape (compartmentalization), and for determining the differential diagnosis in psychiatric disorders ${ }^{5}$.

The correlation between HAND and the HIV viral load in the CSF is dependent on the degree of immunosuppression. In cases with a CD4 count of $>200$ cells $/ \mathrm{mm}^{3}$, the HIV viral load in the CSF correlates positively with that in the peripheral blood, but not with HAND. After the initiation of ARV therapy, the HIV viral load in the CSF and blood decreases. In patients with a CD4 count of $<200$ cells $/ \mathrm{mm}^{3}$, the HIV viral load in the CSF correlates positively with cognitive symptoms, but not with the peripheral blood viral load. The initiation of ARV treatment leads to a decrease in the CSF viral load, although the decrease is slower than the decrease in the blood ${ }^{32,33,34}$.

Opportunistic infections and co-infections increase the HIV viral load in the peripheral blood. Some opportunistic infections or co-infections in the CNS can increase the viral load in the CSF, as noted in patients with neurosyphilis ${ }^{35}$.

Automated methods, commercially available, for quantifying HIV RNA in blood samples have not been standardized for CSF analysis.

\section{COMPARTMENTALIZATION OF HIV IN THE CNS}

Specific CNS immunological characteristics, the blood-brain barrier (BBB), rapid mutation and recombination of HIV, and poor ARV penetration in CNS contribute to the compartmentalization of HIV in the CNS.

Some organs, such as the CNS, genital tract, and gastrointestinal lymphoid tissue, are viral compartments and reservoirs that allow HIV to persist despite ARV therapy that eliminates the virus from the peripheral blood.Compartments are defined as anatomical regions that restrict the genetic flow of HIV, thereby enabling viral evolution and divergence from the virus circulating in the peripheral blood. On the other hand, reservoirs are cells or anatomical sites where HIV or HIV-infected cells survive because the viral kinetics is slower than that in the peripheral blood. Compartments and reservoirs protect HIV from specific immune responses, 
ARV therapy, and biochemical changes, thereby providing an environment for pathogen-host interactions ${ }^{36,37}$.

The CNS serves as an important reservoir for HIV $36,38,39$. Several constitutional characteristics specific to the CNS support the view that the CNS is an immunologically privileged site. The BBB is composed of endothelial cells that selectively restrict the passage of cell components and macromolecules from the systemic circulation to the CNS. CNS cells rarely express proteins with immunological properties, such as MHC class I and II. In addition, the CNS lacks a lymphatic system ${ }^{40,41,42,43}$.

HIV can infect two types of cells in the CNS: cells derived from monocytes (microglia and macrophages) and astrocytes ${ }^{3}$. The neurological symptoms of HIV, which are the same as systemic symptoms, change dramatically after the introduction of ARV treatment.

In treatments with a combination of ARV drugs, the main objective is to suppress HIV replication in all cells and tissues? ${ }^{7}$ Effective treatment of HAND probably entails complete suppression of HIV replication in the CNS. Incomplete suppression of the virus in the CNS, caused by factors such as lack of ARV penetration in the CNS, can promote viral mutations and resistance to ARV drugs, both of which allow the virus to redistribute to non-CNS tissues. In this context, the CNS is considered a possible reservoir or sanctuary for HIV ${ }^{44}$.

HIV exhibits high genetic and antigenic variability. Mutation and recombination are the main mechanisms that underlie the genetic diversity of HIV and the evolution of the HIV-1 pandemic ${ }^{45,46}$. The high genetic diversity of HIV can be attributed to the lack of a control mechanism for reverse transcriptase activity and the consequently high error rate (0.2-2 mutations per genome per cycle), in association with a high replication rate accompanied by rapid viral turnover ${ }^{47,48}$. Reverse transcriptase does not have 3'-exonuclease regulatory activity and therefore cannot ensure that the DNA transcribed is an accurate copy of the RNA ${ }^{49}$.
The env and gag genes in the HIV-1 subtypes differ by approximately $20 \%$ and $15 \%$, respectively ${ }^{50}$; fewer differences, greater than $1 \%$, characterize quasispecies. The nucleotide sequences of different groups (M, N, O, and P) differ by $30 \%$, and the nucleotide sequences of different types (HIV- 1 and HIV-2) differ by approximately $50 \%^{51}$.

The failure of some ARV drugs to penetrate the CNS contributes to persistent neurocognitive deficits and allows for slow replication in the CNS. The improvement of neurocognitive performance after 12 weeks of HAART is greater in those who receive ARV drugs with better CNS penetration ${ }^{52}$.

Despite the limited CNS penetration of most ARV drugs, HAART is partially effective in suppressing HIV replication in the CNS. Although some HAART-based treatments are better than others with regard to CNS penetration ${ }^{34}$, ARV drugs must be selected to prevent viral activity in the CNS, limit neuron dysfunction, and prevent or treat HIV-infected patients with HAND. In addition, these strategies may help prevent the development of ARV resistance ${ }^{53}$. Table 3 shows the ARV CNS penetration according to the index of ARV CNS penetration effectiveness $(\mathrm{CPE})^{53}$.

Despite the effective suppression of viremia with ARV therapy, HIV can still replicate in the CNS, with the development of resistant strains in the CNS in patients with acute and sub-acute neurological manifestations ${ }^{38,39,54}$. Disagreement between the HIV viral loads in the plasma and CSF is defined by detectable levels of HIV RNA in the CSF, indicative of a viral load of $>200$ copies $/ \mathrm{mL}$, when the viral load in the plasma is $<50$ copies/mL or by an HIV RNA viral load in the CSF that is $\geq 1 \log$ higher than that in the plasma ${ }^{55}$.

Different concentrations of ARV drugs have been found in the CSF. Therefore, the use of ARV drugs that penetrate the $\mathrm{BBB}$ is considered necessary to control infection in the CNS in patients at an advanced stage of the disease, particularly those with neurological problems. Compartmentalization of HIV-1 infection in the CNS can affect the response to

Table 3. Index of ARV central nervous system penetration effectiveness (CPE) ${ }^{53}$.

\begin{tabular}{|c|c|c|c|c|}
\hline & 4 & 3 & 2 & 1 \\
\hline \multirow[t]{2}{*}{ NRTIS } & Zidovudine & Abacavir & Didanosine & Tenofovir \\
\hline & & Emtricitabine & $\begin{array}{l}\text { Lamivudine } \\
\text { Stavudine }\end{array}$ & Zalcitabine \\
\hline NNRTIs & Nevirapine & $\begin{array}{l}\text { Delavirdine } \\
\text { Efavirenz }\end{array}$ & Etravirine & \\
\hline \multirow[t]{5}{*}{ Pls } & Indinavir-r & Darunavir-r & Atazanavir & Nelfinavir \\
\hline & & Fosamprenavir-r & Atazanavir-r & Ritonavir \\
\hline & & Indinavir & Fosamprenavir & Saquinavir-r \\
\hline & & Lopinavir-r & & Saquinavir-r \\
\hline & & & & Tipranavir-r \\
\hline \multicolumn{5}{|c|}{ Entry/Fusion } \\
\hline Inhibitors & & Maraviroc & & Enfuvirtide \\
\hline \multicolumn{5}{|l|}{ Integrase } \\
\hline Inhibitors & & Raltegravir & & \\
\hline
\end{tabular}


treatment, which can lead to the development of varying degrees of resistance to ARV drugs in both compartments. Although tests for HIV-1 resistance in the CSF are not recommended during routine treatment of individuals with ARV failure, the choice of treatment in patients with neurological problems requires knowledge of the resistance profile of the virus in the $\mathrm{CSF}^{56,57}$.

Because lumbar puncture is an invasive procedure, researchers have attempted to develop a predictive model with which to estimate the risk of detectable RNA in the CSF (threshold of > 50 copies $/ \mathrm{mL}$ ) and help identify HIV-positive patients who would benefit most from CSF monitoring. The variables included in the predictive model are race, major depressive disorder (MDD), adherence to ARV, AVR CNS penetration effectiveness (CPE), plasma HIV RNA quantification, and duration of current antiretroviral therapy (ART).
However, the CSF-HIV risk score for assessing HIV activity in the CNS requires further validation ${ }^{58}$.

Final remarks, CSF analysis has a well-defined and valuable role in the diagnosis of CNS opportunistic infections and co-infections in HIV/AIDS patients. Although further research is necessary to establish a clinically applicable biomarker for HAND diagnosis, promising CSF biomarkers include neopterin, MCP-1, IP-10, and light neurofilaments.

Because of its constitutional and immunological characteristics, the CNS can act as a reservoir for HIV. HIV can replicate in the CNS, independent of HIV in the peripheral blood, and compartmentalization can occur, with the development of quasispecies. Determination of the HIV viral load in the CSF is important for assessing the compartmentalization of HIV in the CNS and for monitoring therapeutic effects.

\section{References}

1. Ministério da Saúde (BR). Programa Nacional de DST/AIDS. Diagnostico da infecção pelo HIV. Manual técnico para o diagnóstico da infecção pelo HIV Brasília, DF: Ministério da Saúde; 2013 [cited 201310 01]. Available from: http://www.aids.gov.br/assistencia/manualdst/item12.htm

2. AVERTing HIV and AIDS. HIV \& AIDS in USA. West Sussex:AVERT; 2014 [cited 2014 Mar]. Available from: http://www.avert.org/hiv-aids-usa.htm\#footnote27_sdg3l0s

3. Price RW. The two faces of HIV infection of cerebrospinal fluid. Trends Microbiol. 2000;8(9):387-91. http://dx.doi.org/10.1016/S0966-842X(00)01821-7

4. Brew BJ, Wesselingh SL, Gonzales M, Heyes MP, Price RW. Managing HIV. How HIV leads to neurological disease. Med J Aust. 1996;164(4):233-4.

5. Tyler KL, McArthur JC. Through a glass, darkly: cerebrospinal fluid viral load measurements and the pathogenesis of human immunodeficiency virus infection of the central nervous system. Arch Neurol. 2002;59(6):909-12. http://dx.doi.org/10.1001/archneur.59.6.909

6. Heaton RK, Clifford DB, Franklin DR Jr, Woods SP, Ake C, Vaida F et al. HIV-associated neurocognitive disorders persist in the era of potent antiretroviral therapy:CHARTER Study. Neurology 2010;75(23):2087-96. http://dx.doi.org/10.1212/WNL.0b013e318200d727

7. Dore GJ, Correll PK, Li Y, Kaldor JM, Cooper DA, Brew BJ. Changes to AIDS dementia complex in the era of highly active antiretroviral therapy. AIDS 1999;13(10):1249-53. http://dx.doi.org/10.1097/00002030-199907090-00015

8. Fishman RA. Cerebrospinal fluid in diseases of the nervous system. 2nd ed. Philadelphia:WB Saunders; 1992.

9. Almeida SM, Ribeiro CE, Pessa LFC, Moreira SR, Vidal LR, Nogueira $M B$ et al. Incidence of neurological manifestations as AIDS defining clinical conditions in Brazil. BMC Proceedings. 2008;2(Supppl 1):45. http://dx.doi.org/10.1186/1753-6561-2-s1-p45

10. Steiner I, Schmutzhard E, Sellner J, Chaudhuri A, Kennedy PGE. EFNSENS guidelines for the use of PCR technology for the diagnosis of infections of the nervous system. Eur J Neurol. 2012;19(10):1278-91. http://dx.doi.org/10.1111/j.1468-1331.2012.03808.x

11. Almeida SM, Zavala JA, Gabardo BM, Ribeiro CE, Rossoni AM, Araújo JM. Acute bacterial meningitis in HIV, patients in southern Brazil: Curitiba, Paraná, Brazil. Arq Neuropsiquiatr. 2007;65(2A):273-8. http://dx.doi.org/10.1590/S0004-282X2007000200016

12. Zink MC, Clements JE. The two faces of HIV infection of cerebrospinal fluid: response. Trends Microbiol. 2000;8(9):390-1. http://dx.doi.org/10.1016/S0966-842X(00)01822-9
13. Almeida SM, Boritza K, Cogo LL, Pessa L, França J, Rota l et al. Quantification of cerebrospinal fluid lactic acid in the differential diagnosis between HIV chronic meningitis and opportunistic meningitis. Clin Chem Lab Med. 2011;49(5):891-6. http://dx.doi.org/10.1515/CCLM.2011.131

14. Almeida SM, Ribeiro CE, Pereira AP, Badiee J, Cherner M, Smith D et al. Neurocognitive impairment in HIV-1 clade Cversus B-infected individuals in Southern Brazil. J Neurovirol. 2013;19(6):550-6. http://dx.doi.org/10.1007/s13365-013-0215-5

15. Antinori A, Arendt G, Becker JT, Brew BJ, Byrd DA, Cherner $M$ et al. Updated research nosology for HIV-associated neurocognitive disorders. Neurology 2007;69(18):1789-99. http://dx.doi.org/10.1212/01.WNL.0000287431.88658.8b

16. Brew BJ, Letendre SL. Biomarkers of HIV related central nervous system disease. Int Rev Psychiatry. 2008;20(1):73-88. http://dx.doi.org/10.1080/09540260701878082

17. Almeida SM, Letendre S, Zimmerman J, Lazzaretto D, McCutchan A, Ellis R. Dynamics of monocyte chemoattractant protein type one (MCP-1) and HIV viral load in human cerebrospinal fluid and plasma.J Neuroimmunol. 2005;169(1-2):144-52. http://dx.doi.org/10.1016/j.jneuroim.2005.07.012

18. Cinque P, Brew BJ, Gisslen M, Hagberg L, Price RW. Cerebrospinal fluid markers in central nervous system HIV infection and AIDS dementia complex. Handb Clin Neurol. 2007;85:261-300. http://dx.doi.org/10.1016/S0072-9752(07)85017-2

19. Gisslen M, Hagberg L, Brew BJ, Cinque P, Price RW, Rosengren L. Elevated cerebrospinal fluid neurofilament light protein concentrations predict the development of AIDS dementia complex. J Infect Dis. 2007;195(12):1774-8. http://dx.doi.org/10.1086/518043

20. Hagberg L, Cinque P, Gisslen M, Brew BJ, Spudich S, Bestetti A et al. Cerebrospinal fluid neopterin: an informative biomarker of central nervous system immune activation in HIV-1 infection. AIDS Res Ther. 2010;7(1):15. http://dx.doi.org/10.1186/1742-6405-7-15

21. Brew BJ, Pemberton L, Blennow K, Wallin A, Hagberg L. CSF amyloid beta42 and tau levels correlate with AIDS dementia complex. Neurology. 2005;65(9):1490-2.http://dx.doi.org/10.1212/01.wnl.0000183293.95787.b7

22. Gisslén M, Krut J, Andreasson U, Blennow K, Cinque P, Brew BJ et al. Amyloid and tau cerebrospinal fluid biomarkers in HIV infection. BMC Neurol. 2009;9(1):63. http://dx.doi.org/10.1186/1471-2377-9-63

23. KrutJJ, Zetterberg H, Blennow K, Cinque P, Hagberg L, Price RW et al. Cerebrospinal fluid Alzheimer's biomarker profiles in CNS infections.J Neurol. 2013;260(2):620-26. http://dx.doi.org/10.1007/s00415-012-6688-y 
24. Krut JJ, Gisslen M, Hagberg L, Zetterberg H, Price RW, Nilsson S et al. Hyperphosphorylated Tau in cerebrospinal fluid: a biomarker for neurological aging in HIV? In: 21 st Conference of Retrovirus and Opportunistic Infections; 2014 Mar 3-6; Boston. New York: National AIDS Treatment Advocacy Project; 2014. Poster 453.

25. Doitsh G, Galloway NLK, Geng X, Yang Z, Monroe KM, Zepeda O et al. Cell death by pyroptosis drives CD4 T-cell depletion in HIV-1 infection. Nature. 2014;505(7484):509-14. http://dx.doi.org/10.1038/nature12940

26. Doitsh G, Galloway NLK, Geng X, Yang Z, Monroe KM, Zepeda O et al. Pyroptosis drives CD4 T-cell death and chronic inflammation in HIV-1 infected lymphoid tissues. In: 21st Conference of Retrovirus and Opportunistic Infections; 2014 Mar 3-6; Boston. New York: National AIDS Treatment Advocacy Project; 2014. Oral presentation 76.

27. Monroe KM, Yang Z, Johnson JR, Geng X, Doitsh G, Krogan NJ et al. IFI16 DNA sensor is required for death of lymphoid CD4 T cells abortively infected with HIV. Science. 2014;343(6169):428-32. http://dx.doi.org/10.1126/science.1243640

28. Neuenburg JK, Cho TA, Nilsson A, Bredt BM, Hebert SJ, Grant RM et al. T-cell activation and memory phenotypes in cerebrospinal fluid during HIV infection. J Acquir Immune Defic Syndr. 2005;39(1):16-22. http://dx.doi.org/10.1097/01.qai.0000155036.03004.a0

29. Gisslen M, Hagberg L, Rosengren L, Brew BJ, Cinque P, Spudish S et al. Defining and evaluating HIV-related neurodegenerative disease and its treatment targets: a combinatorial approach to use of cerebrospinal fluid molecular biomarkers. J Neuroimmune Pharmacol. 2007;2(1):112-9. http://dx.doi.org/10.1007/s11481-006-9035-1

30. Lipman M, Breen R. Immune reconstitution inflammatory syndrome in HIV. Curr Opin Infect Dis. 2006;19(1):20-5. http://dx.doi.org/10.1097/01.qco.0000200543.80712.01

31. Venkataramana A, Pardo CA, McArthur JC, Kerr DA, Irani DN, Griffin JW et al. Immune reconstitution inflammatory syndrome in the CNS of HIV-infected patients. Neurology. 2006;67(3):383-8. http://dx.doi.org/10.1212/01.wnl.0000227922.22293.93

32. Ellis RJ, Hsia K, Spector SA, Nelson JA, Heaton RK, Wallace MR et al. Cerebrospinal fluid human immunodeficiency virus type 1 RNA levels are elevated in neurocognitively impaired individuals with acquired immunodeficiency syndromeAnn Neurol. 1997;42(5):679-88. http://dx.doi.org/10.1002/ana.410420503

33. Ellis RJ, Moore DJ, Childers ME, Letendre S, McCutchan JA, Wolfson Tet al. Progression to neuropsychological impairment in human immunodeficiency virus infection predicted by elevated cerebrospinal fluid levels of human immunodeficiency virus RNA. Arch Neurol. 2002;59(6):923-8. http://dx.doi.org/10.1001/archneur.59.6.923

34. Langford D, Marquie-BeckJ, Almeida S, Lazzaretto D, Letendre S, Grant I et al. Relationship of antiretroviral treatment to postmortem brain tissue viral load in human immunodeficiency virus-infected patients.J Neurovirol. 2006;12(2):100-7.http://dx.doi.org/10.1080/13550280600713932

35. Almeida SM, Ellis R, Letendre S, McCutchan JA, Grant I. Cerebrospinal fluid human immunodeficiency virus viral loaad in patients with neurosyphilis. J Neurovirol. 2010;16(1):6-12. http://dx.doi.org/10.3109/13550280903514776

36. Karris MA, Smith DM. Tissue-specific HIV-1 infection: why it matters. Future Virol. 2011;6(7):869-82. http://dx.doi.org/10.2217/fvl.11.48

37. North TW, Higgins J, Deere JD, Hayes TL, Villalobos A, Adamson L et al. Viral sanctuaries during highly active antiretroviral therapy in a nonhuman primate model for AIDS. J Virol. 2010;84(6):2913-22. http://dx.doi.org/10.1128/JVI.02356-09

38. Zárate S, Pond SLK, Shapshak P, Frost SDW. Comparative study of methods for detecting sequence compartmentalization in human immunodeficiency virus type 1.J Virol. 2007;81(12):6643-51. http://dx.doi.org/10.1128/JVI.02268-06

39. Haggerty S, Stevenson M. Predominance of distinct viral genotypes in brain and lymph node compartments of HIV-1-infected individuals. Viral Immunol. 1991;4(2):123-31. http://dx.doi.org/10.1089/vim.1991.4.123

40. Clyde F, Barker CF, Billingham RE. Immunologically privileged sites. Adv Immunol. 1978;25:1-54. http://dx.doi.org/10.1016/S0065-2776(08)60930-X
41. Kreutzberg GW. Microglia: a sensor for pathological events in the CNS. Trends Neurosci. 1996;19(8):312-8. http://dx.doi.org/10.1016/0166-2236(96)10049-7

42. Sedgwick JD, Ford AL, Foulcher E, Airriess R. Central nervous system microglial cell activation and proliferation follows direct interaction with tissue-infiltrating T cell blasts. J Immunol. 1998;160(11):5320-30.

43. Shrikant P, Benveniste EN. The central nervous system as an immunocompetent organ: role of glial cells in antigen presentation. J Immunol. 1996;157(5):1819-22.

44. Abbott NJ. Glia and the blood: brain barrier. Nature. 1987;325(6101):195. http://dx.doi.org/10.1038/325195a0

45. Thomson MM, Nájera R. Molecular epidemiology of HIV-1 variants in the global AIDS pandemic: an update. AIDS Rev. 2005;7(4):210-24.

46. Nájera R, Delgado E, Pérez-Alvarez L, Thomson MM. Genetic recombination and its role in the development of the HIV-1 pandemic. AIDS. 2002;16 Suppl 4:S3-16.

47. Korber B, Gaschen B, Yusim K, Thakallapally R, Kesmir C, Detours $V$. Evolutionary and immunological implications of contemporary HIV-1 variation. Br Med Bull. 2001;58(1):19-42. http://dx.doi.org/10.1093/bmb/58.1.19

48. Domingo E. Quasispecies and the implications for virus persistence and escape. Clin Diagn Virol. 1998;10(2-3):97-101. http://dx.doi.org/10.1016/S0928-0197(98)00032-4

49. Perelson AS, Neumann AU, Markowitz M, Leonard JM, Ho DD. HIV-1 dynamics in vivo: virion clearance rate, infected cell life-span, and viral generation time. Science. 1996;271(5955):1582-6. http://dx.doi.org/10.1126/science.271.5255.1582

50. Brew BJ. HIV neurology. Oxford, UK: Oxford University Press; 2001.

51. Ariën KK, Vanham G, Arts EJ. Is HIV-1 evolving to a less virulent form in humans? Nat Rev Microbiol. 2007;5(2):141-51. http://dx.doi.org/10.1038/nrmicro1594

52. Cysique LA, Vaida F, Letendre S, Gibson S, Cherner M, Woods SP et al. Dynamics of cognitive change in impaired HIV-positive patients initiating antiretroviral therapy. Neurology. 2009;73(5):342-8. http://dx.doi.org/10.1212/WNL.0b013e3181ab2b3b

53. Letendre S, Ellis R, Deuthsch R, et al (Autor, favor citar mais três autores e informar se são somente os 6 . Devem ser citados seis autores e et al. para mais). In: 17th Conference on Retrovirus and Opportunistic Infections; 2010 Feb 16-19; San Francisco. New York: National AIDS Treatment Advocacy Project; 2010. Poster 430.

54. Harrington PR, Schnell G, Letendre SL, Ritola K, Robertson K, Hall C et al. Cross-sectional characterization of HIV-1 env compartmentalization in cerebrospinal fluid over the full disease course. AIDS. 2009;23(8):907-15. http://dx.doi.org/10.1097/QAD.0b013e3283299129

55. Canestri A, Lescure FX, Jaureguiberry S, Moulignier A, Amiel C, Marcelin AG et al. Discordance between cerebral spinal fluid and plasma HIV replication in patients with neurological symptoms who are receiving suppressive antiretroviral therapy. Clin Infect Dis. 2010;50(5):773-8. http://dx.doi.org/10.1086/650538

56. Antinori A, Cingolani A, Giancola ML, Forbici F, De Luca A, Perno CF. Clinical implications of HIV-1 drug resistance in the neurological compartment. Scand J Infect Dis Suppl. 2003;35(s106):41-4. http://dx.doi.org/10.1080/03008870310009650

57. Rotta I, Raboni SM, Ribeiro CEL, Riedel M, Winhescki MG, Smith DM et al. Cerebrospinal fluid can be used for HIV genotyping when it fails in blood. Arq Neuropsiquiatr. 2014;72(7):506-9. http://dx.doi.org/10.1590/0004-282X20140093

58. Hammond ER, Crum RM, Treisman GJ, Mehta SH, Marra CM, Clifford DB et al. The cerebrospinal fluid HIV risk score for assessing central nervous system activity in persons with HIV. Am J Epidemiol. 2014;180(3):297-307. http://dx.doi.org/10.1093/aje/kwu098

59. Rahimy E, Spudich S, Li F, Hagberg L. Longitudinal Assessment of Blood Brain Barrier Disruption in Primary HIV Infection. In: 17th Conference on Retrovirus and Opportunistic Infections; 2010 Feb 16-19; San Francisco. New York: National AIDS Treatment Advocacy Project; 2010. Abstract 60. 